ISSN: 2302-8556

E-Jurnal Akuntansi Universitas Udayana

Vol.22.1. Januari (2018): 438-463

DOI: https://doi.org/10.24843/EJA.2018.v22.i01.p17

\title{
Pengaruh Pengalaman, Due Professional Care dan Akuntabilitas Auditor Pada Kualitas Audit
}

\author{
Ni Made Widia Iswara Dewi ${ }^{1}$ \\ I Putu Sudana ${ }^{2}$
}

\author{
${ }^{1}$ Fakultas Ekonomi dan Bisnis Universitas Udayana (Unud), Bali, Indonesia \\ e-mail: madewidiaiswaradewi@yahoo.co.id /Tlp: (0361) 701810 \\ ${ }^{2}$ Fakultas Ekonomi dan Bisnis Universitas Udayana (Unud), Bali, Indonesia
}

\begin{abstract}
ABSTRAK
Kualitas audit merepresentasikan kinerja auditor dalam melaksanakan tugas yang diembannya. Kualitas audit merupakan hasil kinerja auditor dalam melaksanakan tugas yang bersangkutan. Auditor dituntut untuk dapat menghasilkan kualitas audit yang tinggi sehingga mempunyai tanggung jawab yang besar terhadap pihak-pihak yang berkepentingan. Adapun tujuan dari penelitian ini untuk mengetahui pengaruh pengalaman, due professional care dan akuntabilitas auditor pada kualitas audit. Auditor dituntut untuk dapat menghasilkan kualitas audit yang tinggi sebagai bagian dari tanggung jawab profesionalnya kepada pihak-pihak yang berkepentingan. Populasi dalam penelitian ini adalah seluruh auditor yang bekerja pada Kantor Akuntan Publik di Bali. Pengambilan sampel dilakukan dengan teknik purposive sampling, dan diperoleh sampel sebanyak 55 responden. Data dikumpulkan dengan survei kuesioner. Data yang terkumpul dianalisis dengan regresi linear berganda. Berdasarkan hasil analisis ditemukan bahwa pengalaman, due professional care dan akuntabilitas berpengaruh positif dan signifikan terhadap kualitas audit. Hal ini menunjukkan bahwa semakin tinggi pengalaman yang dimiliki oleh auditor maka keputusan yang diambil akan semakin dapat dipertanggungjawabkan. Penggunaan due professional caredengan seksama dan cermat akan memberikan keyakinan yang memadai pada auditor untuk memberikan opini bahwa laporan keuangan terbebas dari salah saji material, baik yang disebabkan oleh kecurangan maupun kekeliruan. Sedangkan apabila akuntabilitas yang dimiliki oleh seorang auditor tinggi maka hasil dari audit yang dilakukan seorang auditor tersebut dapat dpertanggungjawabkan.
\end{abstract}

Kata kunci: Pengalaman, Due Profesional Care, Akuntabilitas Auditor, Kualitas Audit

\begin{abstract}
Audit quality represents the result of auditor performance in carrying out the task concerned. Audit quality is the result of auditor performance in carrying out the task concerned. Auditors are required to produce high audit quality so as to have a great responsibility to the parties concerned. The purpose of this study to determine the influence of experience, due professional care and auditor accountability on audit quality.Auditors are required to produce high audit quality so as to have a great responsibility to the interested parties. Populations in this study are all auditors who work at Public Accounting Firms in Bali. Respondents are selected using purposive sampling method, and the numbers of samples are 55 respondents. Data were collected by survey questionnaires. Data are analysed using multiple linear regressions. Based on the results of analysis, this study concluded that auditor's experience, due professional care and accountability has a positive impact on audit quality.Based on the analysis results found that experience, due professional care and accountability have a positive and significant impact on audit quality. This indicates that the higher the experience of the auditor will be the more accountable the decision will be made. The careful use of due care carefully will provide reasonable assurance to the auditor to provide an opinion that the financial statements are free from material misstatements, whether caused by fraud or mistakes. Whereas if the accountability possessed by a high auditor then the results of audits made an auditor can be accounted for.

Keywords: Experience, Due Professional Career, Auditor Accountability, Quality Audit
\end{abstract}




\section{PENDAHULUAN}

Kualitas audit merupakan hal yang sangat penting bagi komunitas bisnis. Kualitasaudit yang tinggi dapat menghasilkan laporan keuangan yang dapat dipercaya sebagai dasar pembuatan keputusan. Kualitas audit yang baik akan mampu meningkatkan kinerja perusahaan bahkan akan mendongkrak citra perusahaan di mata masyarakat. DeAngelo (1981) mendefinisikan kualitas audit sebagai probabilitas, dimana seorang auditor menemukan dan melaporkan adanya pelanggaran dalam sistem akutansi kliennya.

Probabilitas untuk menemukan kesalahan tergantung pada independensi auditor (Deis dan Giroux, 1992). Elfarini (2007) mengatakan bahwa kualitas audit adalah seluruh probabilitas auditor pada saat mengaudit laporan keuangan klien dapat menemukan kesalahan yang terjadi pada sistem akuntansi klien dan mengungkapkannya dalam laporan keuangan auditan. Dalam menjalankan tanggung jawabnya auditor mengacu pada standar auditing dan kode etik akuntan publik yang penting.

Salah satu esensi dari kualitas audit adalah kesediaan auditor untuk melaporkan setiap manipulasi materi atau salah saji yang akan meningkatkan ketidakpastian material (Bradshaw et al., 2001). Laporan keuangan tanpa asimetri informasi dan salah saji membuktikan adanya kualitas audit (Edosa et al., 2013). Menurut Rosnidah (2010) kualitas audit ditentukan oleh pelaksanaan proses audit yang dilakukan sesuai dengan standar sehingga mampu mengungkapkan dan melaporkan pelanggaran yang dilakukan oleh pihak klien. Salah satu atribut kualitas audit adalah standar etika yang 
tinggi, atribut lainnya berkenaan dengan kompetensi auditor (Cushing, 1999). Kualitas audit yang baik pada prinsipnya dapat dicapai jika auditor menerapkan standar-standar dan prinsip-prinsip audit, bersikap bebas tanpa memihak, patuh pada hukum serta menaati kode etik profesi.

Standar Profesional Akuntan Publik (SPAP) merupakan tolak ukur pemeriksaan akuntan publik, mengontrol seluruh hal yang bersangkutan dengan penugasan, independensi dalam sikap mental. Namun selain standar audit, akuntan publik juga harus mematuhi kode etik profesi yang mengatur perilaku akuntan publik dalam menjalankan praktik profesi, kompetensi dan kehati-hatian profesional, kerahasiaan, perilaku profesional serta standar teknis bagi seorang auditor dalam menjalankan profesinya (Kovinna dan Betri, 2013)

Menurut Louwers et al., (2008), kegagalan audit dalam kasus fraud transaksi pihak-pihak terkait disebabkan karena kurangnya sikap skeptik dan due professional care. Kualitas audit semakin mendapat perhatian publik, setelah terjadinya kasus atau skandal keuangan baik didalam maupun diluar negeri.Profesi akuntan publik adalah profesi yang sangat penting. Namun, integritas dan objektivitas para akuntan publik dapat diragukan oleh pihak-pihak yang berkepentingan sejalan dengan maraknya skandal-skandal keuangan. Bawono dan Singgih (2010) menyebutkan bahwa makin banyaknya skandal keuangan yang terjadi di luar maupun di dalam negeri sangat mempengaruhi kepercayaan pengguna laporan keuangan auditan pada profesi akuntan publik. 
Sebagai salah satu pemegang peran penting dalam dunia bisnis, terjadinya kasus atau skandal keuanganmenyebabkan integritas, objektivitas dan kinerja dari seorang auditor diragukan. KAP perlu meningkatkan kualitas audit untuk meningkatkan integritas auditor agar kembali dapat dipercaya oleh pihak yang berkepentingan. KAP harus memberi perhatian pada aspek-aspek penting yang menentukan kualitas audit, yakni pengalaman kerja, sikap due professional care, dan akuntabilitas auditor.

Mengimplementasikan suatu aktivitas audit, auditor diharuskan untuk melaksanakan pekerjaannya dengan profesionalitas yang tinggi. Kemampuan yang dimiliki oleh auditor tidak sekedar dipengaruhi oleh pengetahuan formal belaka akan tetapi ditentukan juga oleh faktor-faktor lain yang menjadi pengalamannya. Tubbs (1992) menyebutkan bahwa auditor yang berpengalaman memiliki keunggulan dalam hal mendeteksi kesalahan, memahami kesalahan secara akurat, dan mencari penyebab kesalahan. Pengalaman auditor dalam melakukan pemeriksaan laporan keuangan menjadi salah satu faktor yang mempengaruhi kualitas audit. Pengetahuan auditor akan semakin berkembang seiring bertambahnya pengalaman melakukan tugas audit. Harhinto (2004) mendeskripsikan bahwa dengan pengalamannya auditor mampu mendapatkan keterampilan dan mengembangkan struktur pengetahuan. Sehingga seorang auditor yang semakin berpengalaman dan profesional maka keputusan yang diambil akan semakin dapat dipertanggungjawabkan. Auditor yang berpengalaman diharapkan dapat memberi tingkat kredibilitas yang lebih tinggi bagi para pemakai laporan auditan. 
ISSN: 2302-8556

E-Jurnal Akuntansi Universitas Udayana

Vol.22.1. Januari (2018): 438-463

Due professional care mengacu pada kemahiran professional yang cermat dan seksama. Kemahiran professional menuntut auditor untuk selalu berpikir kritis terhadap bukti audit yang ditemukannya. Bawono dan Singgih (2010) mendefinisikan due professional care sebagai kecermatan dan keseksamaan dalam penggunaan kemahiran profesional yang menuntut auditor untuk melaksanakan skeptisme profesional. Due professional care merupakan hal penting yang harus diterapkan oleh para akuntan publik agar tercapainya kualitas audit yang memadai dalam pelaksanaan pekerjaan profesionalnya.

Messier dan Quilliam (1992) mengatakan bahwa akuntabilitas yang dimiliki oleh seorang auditor dapat meningkatkan proses kognitif auditor dalam pengambilan keputusan yang berpengaruh terhadap kualitas audit. Lalu Bawono dan Singgih (2010) meneliti tentang akuntabilitas yang dilihat dari 3 (tiga) segi yaitu motivasi, pengabdian pada profesi dan kewajiban sosial juga berpengaruh terhadap kualitas audit baik secara parsial maupun simultan.

Berpengaruhnya penerapan etika profesi akuntan publik merupakan dasar yang penting dalam berperilaku baik dalam suatu profesi. Belakangan ini banyak sekali kesalahan dan penyelewengan yang mengemukaimbas dari penggunaan etika profesi yang tidak maksimal. Banyak penyelewengan-penyelewangan yang mengemukaatas terkikisnya kejujuran dan kebijaksanaan dalam berperilaku. Kejadian inilah yangmembawa dampak kualitas hasil auditan yang dikeluarkan oleh auditor menjadi rendah. 
Akuntabilitas merupakan wujud kewajiban seseorang untuk mempertanggungjawabkan pengelolaan atas kewenangan yang dipercayakan kepadanya guna pencapaian tujuan yang ditetapkan. Seorang akuntan publik wajib untuk menjaga perilaku etis mereka kepada profesi, masyarakat dan pribadi mereka sendiri agar senantiasa bertanggungjawab untuk menjadi kompeten dan berusaha objektif dan menjaga integritas sebagai akuntan publik (Bawono dan Singgih, 2010).

Beberapa penelitian telah dilakukan untuk mengetahui hubungan dan pengaruh pengalaman, due professional care dan akuntabilitas auditor pada kualitas audit. Pengalaman dalam pemeriksaan laporan keuangan menjadi salah satu faktor yang mempengaruhi kualitas audit. Pengalaman bagi auditor dalam bidang audit berperan penting dalam meningkatkan pengetahuan dan keahlian yang diperoleh auditor dari pendidikan formalnya sehingga kualitas audit akan semakin baik seiring bertambahnya pengalaman. Penelitian yang dilakukan oleh Satyawati (2009), Saripudin, dkk (2012), Bawono dan Singgih (2010) serta Randi (2014) menemukan bahwa variabel pengalaman kerja berpengaruh terhadap kualitas audit.

Penelitian Louwers, et al. (2008) mengungkapkan auditor yang kurang menggunakan sikap skeptis dan due professional care cenderung gagal dalam mengungkapkan fraud dalam penyajian laporan keuangan perusahaan. Penggunaan due professional care dengan seksama dan cermat akan memberikan keyakinan yang memadai pada auditor untuk memberikan opini bahwa laporan keuangan terbebas dari salah saji material, baik yang disebabkan oleh kecurangan maupun kekeliruan. Semakin baik penggunaan due professional care auditor memungkinkan hasil audit 
ISSN: 2302-8556

E-Jurnal Akuntansi Universitas Udayana

Vol.22.1. Januari (2018): 438-463

yang lebih baik, juga didalam beberapa penelitian seperti Bawono dan Singgih (2010) dan Febriyanti R (2014) bersependapat bahwa due professional care mempengaruhi kualitas audit.

Diana dan Ria (2007) menyebutkan tanggung jawab (akuntabilitas) auditor dalam melaksanakan audit akan mempengaruhi kualitas audit yang dihasilkan. Akuntan yang memiliki kesadaran akan pentingnya peranan akuntan bagi profesi dan masyarakat, ia akan melakukan pekerjaannya dengan sebaik mungkin. Begitu pula menurut penelitian yang dilakukan oleh Saripudin, dkk (2012), Bawono dan Singgih (2010) bersependapat bahwa akuntabilitas dapat mempengaruhi kualitas audit.

Penelitian-penelitian sebelumnya memberikan bukti secara empiris bahwa pengalaman auditor, due professional care dan akuntabilitas berpengaruh positif terhadap kualitas audit. Namun adapula beberapa penelitian yang membuktikan bahwa faktor-faktor ini tidak berpengaruh secara signifikan terhadap kualitas audit. Penelitianyang dilakukan oleh Astrini (2014), Badjuri (2011), Kovinna dan Betri (2014), Iskandar (2014) serta Bawono dan Singgih (2010) membuktikan bahwa pengalaman kerja tidak berpengaruh terhadap kualitas audit. Saripudin, dkk (2012), Randi (2014), Iskandar (2014) menemukan bahwa due professional care tidak berpengaruh terhadap kualitas audit. Selain itu penelitian yang dilakukan oleh Tan dan Kao (1999), Randi (2014), Febriyanti (2014) yang membuktikan bahwa akuntabilitas tidak berpengaruh terhadap kualitas audit. Inkonsistensi temuan pada penelitian-penelitian sebelumnya melandasi dilakukannya penelitian ini dengan menggunakan Kantor Akuntan Publik di Bali sebagai lokasi risetnya. 
Teori keperilakuan menjelaskan hubungan antar variabel pengalaman auditor dengan kualitas audit.Teori keperilakuan yaitu suatu ilmu yang mempelajari perilaku manusia. Dalam ilmu keperilakuan terdapat tiga kontributor utama, yaitu psikologi, sosiologi, dan psikologi sosial. Psikologi dan psikologi sosial memberikan kontribusi banyak dalam perkembangan keperilakuan yaitu kepribadian, sikap, motivasi, persepsi, nilai, dan pembelajaran (Hudayati, 2002). Auditor yang tidak berpengalaman akan melakukan atribusi kesalahan lebih besar dibandingkan dengan auditor yang berpengalaman (Wasito dan Ghozali, 2002:6). Jadi pengalaman mempengaruhi perilaku auditor yang kemudian akan mempengaruhi kualitas audit.Asih (2010) mengatakan bahwa pengalaman merupakan suatu proses pembelajaran dan penambahan perkembangan potensi bertingkah laku baik dari pendidikan formal maupun pendidikan non formal atau bisa juga diartikan sebagai suatu proses yang membawa seseorang kepada suatu pola tingkah laku yang lebih tinggi. Selain itu pengalaman kerja seseorang dapat meningkatkan keterampilan dan pengetahuan seseorang dalam bekerja.Dalam penelitian Bernardin (1994) mengatakan bahwa pengalaman merupakan faktor yang mempengaruhi kemampuan prediksi dan deteksi auditor. Selain itu penelitian Bawono dan Singgih (2010) pengalaman memiliki beberapa faktor yang mempengaruhi yaitu meliputi lamanya menjadi auditor, sesuai dengan jabatan dan masa kerja di KAP pengalaman auditor terus bertambah terutama dalam praktik audit. Auditor dapat menyelesaikan pekerjaan sesuai prosedur karena pengalaman yang dimiliki. Adapun frekuensi pekerjaan pemeriksaan, auditor mengetahui prosedur audit seiring frekuensi 
ISSN: 2302-8556

E-Jurnal Akuntansi Universitas Udayana

Vol.22.1. Januari (2018): 438-463

mengaudit yang telah dilakukannya. Auditor paham karakter jenis perusahaan tertentu karena sering mengaudit jenis perusahaan tersebut.Berdasarkan uraian diatas, maka hipotesis penelitian ini adalah:

$\mathrm{H}_{1}$ : Pengalaman auditor berpengaruh positif pada kualitas audit

Teori keperilakuan juga dapat digunakan untuk menjelaskan hubungan antara variable due professional care dengan kualitas audit. Due professional care memiliki arti kemahiran profesional yang cermat dan seksama (International Standard Auditing, 2012). Auditor harus menggunakan keahlian profesionalnya dengan cermat dan seksama (due professional care) dalam setiap penugasannya. Kecermatan dan keseksamaan menekankan tanggungjawab setiap petugas audit yang bekerja pada suatu Kantor Akuntan Publik untuk mendalami standar pekerjaan lapangan dan standar pelaporan dengan semestinya. Semakin baik penggunaan due professional care auditor memungkinkan hasil audit yang lebih baik, juga didalam beberapa penelitian seperti Bawono dan Singgih (2010) dan Febriyanti (2014) bersependapat bahwa due professional care mempengaruhi kualitas audit.Berdasarkan uraian diatas, maka hipotesis penelitian ini adalah:

$\mathrm{H}_{2}$ : Due professional care berpengaruh positif pada kualitas audit

Teori keperilakuan menjelaskan hubungan antara variable akuntabilitasdengan kualitas audit. Robbins (2008) mendefinisikan motivasi sebagai proses yang menjelaskan intensitias, arah dan ketekunan seorang individu untuk mencapai tujuannya. Jika dikaitkan dengan dunia kerja motivasi merupakan dorongan yang tumbuh dalam diri seseorang, baik yang berasal dari dalam dan luar dirinya untuk 
melakukan sesuatu pekerjaan dengan semangat tinggi menggunakan semua kemampuan dan keterampilan yang dimilikinya.

Penelitian yang dilakukan oleh Lilis (2010) menguji akuntabilitas terhadap kualitas audit. Hasil penelitian ini menunjukan bahwa akuntabilitas berpengaruh signifikan terhadap kualitas audit. Sejalan dengan penelitian yang dilakukan Bawono dan Singgih (2010) yang memberi hasil bahwa akuntabilitas memberi pengaruh secara signifikan terhadap kualitas audit (Febriyanti R, 2010). $\mathrm{H}_{3}$ : Akuntabilitas berpengaruh positif pada kualitas audit

\section{METODE PENELITIAN}

Penelitianini dilakukan pada Kantor Akuntan Publik yang berada di wilayah Bali dan terdaftar pada Institut Akuntan Publik Indonesia 2016 (Tabel 1).Obyek dari penelitian ini adalah Pengaruh Pengalaman, Due Professional Care dan Akuntabilitas Auditor Pada Kualitas Audit. Penelitian ini bertujuan untuk mengkaji pengaruh pengalaman, due professional care dan akuntabilitas auditor pada kualitas audit. Untuk meneliti obyek tersebut diadakan penelitian terhadap auditor untuk dijadikan sampel penelitian. Variabel bebas dalam penelitian ini adalah pengalaman auditor, due professional care dan akuntabilitas, sedangkan variabel terikatnya adalah kualitas audit. Penelelitian ini menggunakan data kuantitatif yakni jawaban kuisioner dari responden yang diangkakan dengan skala Likert. Populasi dalam penelitian ini adalah auditor yang bekerja pada Kantor Akuntan Publik di Bali. Sampel ditentukan dengan teknik purposive sampling(Indriantoro dan Supomo, 2002:124) dan diperoleh 55 responden. 
ISSN: 2302-8556

E-Jurnal Akuntansi Universitas Udayana

Vol.22.1. Januari (2018): 438-463

\section{Tabel 1.}

\section{Daftar KAP di Bali}

\begin{tabular}{|c|c|c|}
\hline No & Nama Kantor Akuntan Publik & Alamat Kantor Akuntan Publik \\
\hline 1. & KAP. Drs Wayan Sunasdyana & $\begin{array}{l}\text { Jl. Pura Demak I Gg Buntu No. 89, Teuku Umar } \\
\text { Barat, Denpasar/Telp } 7422329\end{array}$ \\
\hline 2. & KAP. Drs. Ida Bagus Djagera & $\begin{array}{l}\text { Jl. Hasanuddin No.1 Denpasar No.1 } \\
\text { Denpasar/Telp (0361) } 227460\end{array}$ \\
\hline 3. & KAP. K.Gunarsa & $\begin{array}{l}\text { Jl. Tukad Banyu Sari Gang } 2 \text { No. } 5 \\
\text { Denpasar/Telp (0361) } 225580\end{array}$ \\
\hline 4. & KAP. Drs. Ketut Muliartha RM \& Rekan & $\begin{array}{l}\text { Gedung Guna Teknosa, Jl. Drupadi No. } 25 \\
\text { Renon, Denpasar/Telp (0361) } 248110\end{array}$ \\
\hline 5. & KAP. Rama Wendra (Cab) & $\begin{array}{l}\text { Grand Sudirman Blok B No. 10. Jl. Jend. } \\
\text { Sudirman, Denpasar/Tlp (0361) } 3073333\end{array}$ \\
\hline 6. & KAP. Drs. Sri Marmo Djogosarkoro & $\begin{array}{l}\text { Jl. Gunung Muria Blok VE No.4, Monang } \\
\text { Maning, Denpasar/Telp (0361) } 480033\end{array}$ \\
\hline 7. & KAP. Drs Ketut Budiartha, Msi & $\begin{array}{l}\text { Jl. Gunung Agung, Perum Padang Pesona Graha } \\
\text { Adi Blok A6 }\end{array}$ \\
\hline 8. & KAP. I Wayan Ramantha & $\begin{array}{l}\text { J1. Rampai No 1A Lantai } 3 \text { Denpasar/Telp (0361) } \\
263643\end{array}$ \\
\hline 9. & KAP. Johan Malonda Mustika \& Rekan (Cab) & $\begin{array}{l}\text { Jl. Muding Indah } 1 \text { No.5 Kuta Utara, } \\
\text { Kerobokan/Telp. (0361) } 434884\end{array}$ \\
\hline
\end{tabular}

Sumber: Ikatan Akuntan Publik Indonesia, 2016

Kuisioner yang disebar berupa daftar pertanyaan maupun pernyataan tertulis kepada responden. Kuisioner yang dipergunakan dalam penelitian ini sebelumnya sudah pernah digunakan oleh Iskandar (2014).Analisis regresi linear berganda digunakan untuk menganalisis pengaruh variabel pengalaman, due professional care dan akuntabilitas auditor pada kulitas audit. Bentukpersamaan analisis regresi linear berganda yang digunakan adalah sebagai berikut:

$$
\mathrm{Y}=\alpha+\beta_{1} \mathrm{X}_{1}+\beta_{2} \mathrm{X}_{2}+\beta_{3} \mathrm{X}_{3}+e
$$

\section{Keterangan:}

Y

$\alpha$

$$
\text { = Kualitas Audit }
$$

$\beta_{1}+\beta_{2}+\beta_{3}$

$=$ Konstanta

$\mathrm{X}_{1}$

= Koefisien Regresi

$\mathrm{X}_{2}$

$\mathrm{X}_{3}$

$=$ Pengalaman Auditor

= Due Professional Care

e

$=$ Akuntabilitas Auditor

$=$ Error 


\section{HASIL DAN PEMBAHASAN}

Statistik deskriptif disajikan dengan memberikan informasi tentang karakteristik variabel penelitian. Ringkasan hasil statistik deskriptif dapat dilihat pada Tabel 2.

Tabel 2.

Hasil Statistik Deskriptif Variabel Penelitian

\begin{tabular}{lrrrrr}
\hline & N & Minimum & Maksimum & Mean & \multicolumn{1}{c}{$\begin{array}{c}\text { Std. } \\
\text { Deviation }\end{array}$} \\
\hline Pengalaman & 55 & 25,00 & 32,00 & 28,7272 & 1,70462 \\
Due Professional Care & 55 & 51,00 & 73,00 & 64,0182 & 5,45178 \\
Akuntabilitas & 55 & 12,00 & 20,00 & 15,7636 & 2,02726 \\
Kualitas Audit & 55 & 27,00 & 35,00 & 31,3091 & 1,92328 \\
Valid N (Listwise) & 55 & & & & \\
\hline Sumber: data primer diolah (2017) & & & &
\end{tabular}

Berdasarkan tabel statistik deskriptif dapat diketahui bahwa nilai rata-rata pengalaman (X1) sebesar 28,72 dengan pencapaian nilai terendah sebesar 25 dan nilai tertinggi sebesar 32 dan nilai standard deviasi sebesar 1,77. Pada variabel $d u e$ professional care sebesar 64,01 dengan pencapaian nilai terendah sebesar 51 dan nilai tertinggi sebesar 73 dan nilai standard deviasi sebesar 5,45. Pada variabel akuntabilitas nilai rata-rata sebesar 15,00 dengan pencapaian nilai terendah sebesar 12 dan nilai tertinggi sebesar 20 dan nilai standard deviasi sebesar 2,0. Pada variabel kualitas audit didapat rata-rata sebesar 31,3 dengan pencapaian nilai terendah sebesar 27 dan nilai tertinggi sebesar 35 dan nilai standard deviasi sebesar 1,92.

Analisis regresi linear berganda digunakan untuk mengetahui pengaruh antara variabel dependen terhadap variabel independen. Dalam penelitian ini analisis regresi linear berganda digunakan untuk mengetahui besarnya pengaruh pengalaman, due professional care dan akuntabilitas auditor pada kualitas audit. 
ISSN: 2302-8556

E-Jurnal Akuntansi Universitas Udayana

Vol.22.1. Januari (2018): 438-463

Tabel 3.

Analisis Regresi Linear Berganda

\begin{tabular}{|c|c|c|c|c|c|c|}
\hline & \multirow[b]{2}{*}{ Model } & \multicolumn{2}{|c|}{$\begin{array}{l}\text { Unstandardized } \\
\text { Coefficients }\end{array}$} & \multirow{2}{*}{$\begin{array}{c}\begin{array}{c}\text { Standardized } \\
\text { Coefficients }\end{array} \\
\text { Beta }\end{array}$} & \multirow[b]{2}{*}{$\mathbf{t}$} & \multirow[b]{2}{*}{ Sig. } \\
\hline & & B & Std. Error & & & \\
\hline \multirow[t]{4}{*}{1} & (Constant) & 2,216 & 2,069 & & 1,071 & ,289 \\
\hline & Pengalaman & ,162 &, 051 & ,144 & 3,166 & ,003 \\
\hline & Due Professional Care & ,270 & ,014 & 767 & 18,944 & ,000 \\
\hline & Akuntabilitas & 452 &, 044 & ,477 & 10,277 & ,000 \\
\hline
\end{tabular}

Sumber: data primer diolah (2017)

$$
Y=2,216+0,162 X_{1}+0,270 X_{2}+0,452 X_{3}
$$

Nilai konstanta a sebesar 2,216 artinya jika variabel pengalaman, due professional care dan akuntabilitas dianggap konstan (tetap atau tidak ada perubahan), maka kualitas audit berpengaruh positif. Nilai koefisien $b_{1}$ sebesar 0,162 artinya jika nilai variabel pengalaman meningkat sebesar satu satuan maka kualitas audit meningkat sebesar 0,162 dengan asumsi variabel due professional care, akuntabilitas auditor tetap konstan. Nilai koefisien $\mathrm{b}_{2}$ sebesar 0,270 artinya jika due professional care meningkat sebesar satu satuan maka kualitas audit meningkat sebesar 0,270 dengan asumsi variabel pengalaman, akuntabilitas auditor tetap konstan.Nilai koefisien $b_{3}$ sebesar 0,452 artinya jika akuntabilitas auditor meningkat sebesar satu satuan maka kualitas audit naik sebesar 0,452 dengan asumsi variabel variabel pengalaman, due professional care tetap konstan.

Tabel 4.

Nilai Koefisien Determinasi (Uji R ${ }^{2}$ )

\begin{tabular}{rrrrrr}
\hline Model & R & R Square & $\begin{array}{l}\text { Adjusted } \\
\text { R Square }\end{array}$ & $\begin{array}{l}\text { Std. Error of } \\
\text { the Estimate }\end{array}$ \\
\hline 1 & &, $960^{\mathrm{a}}$ &, 922 &, 918 &, 55207 \\
\hline
\end{tabular}

Sumber: data primer diolah (2017) 
Berdasarkan Tabel 4 nilaiadjustedR ${ }^{2}$ sebesar 0,918 , ini berarti sebesar 91,8 persen variabel pengalaman, due professional care, dan akuntabilitas auditor mempengaruhi kualitas audit sedangkan sisanya sebesar 8,2 persen dipengaruhi oleh variabel lain yang tidak dimasukan dalam penelitian.

Tabel 5.

Uji Kelayakan Model (Uji F)

\begin{tabular}{llrrrrr}
\hline Model & & Sum Of & \multicolumn{4}{c}{ Mean } \\
Squares & Df & Square & \multicolumn{1}{c}{ F } & \multicolumn{1}{c}{ Sig } \\
\hline 1 & Regression & 184.022 & 3 & 61,401 & 201,461 &, $000^{\mathbf{a}}$ \\
& Residual & 15,544 & 51 &, 305 & & \\
& Total & 199,745 & 54 & & & \\
\hline
\end{tabular}

Sumber: data primer diolah (2017)

Berdasarkan Tabel 5 diperoleh nilai dari signifikansi 0,000 yang lebih kecil dari 0,05. Ini berarti bahwa ada pengaruh antara variabel pengalaman, due professional care, dan akuntabilitas auditorsecara simultan terhadap variabel kualitas audit.

Tabel 6.

\section{Uji Hipotesis (Uji t)}

\begin{tabular}{|c|c|c|c|c|c|c|}
\hline & \multirow[b]{2}{*}{ Model } & \multicolumn{2}{|c|}{$\begin{array}{c}\text { Unstandardized } \\
\text { Coefficients }\end{array}$} & \multirow{2}{*}{$\begin{array}{c}\begin{array}{c}\text { Standardized } \\
\text { Coefficients }\end{array} \\
\text { Beta }\end{array}$} & \multirow[b]{2}{*}{$\mathbf{t}$} & \multirow[b]{2}{*}{ Sig. } \\
\hline & & B & Std. Error & & & \\
\hline \multirow[t]{4}{*}{1} & (Constant) & 2,216 & 2,069 & & 1,071 & ,289 \\
\hline & Pengalaman &, 162 &, 051 & ,144 & 3,166 & ,003 \\
\hline & Due Professional Care & ,270 & ,014 & ,767 & 18,944 & ,000 \\
\hline & Akuntabilitas & ,452 & ,044 & ,477 & 10,277 & ,000 \\
\hline
\end{tabular}

Sumber: data primer diolah (2017)

Berdasarkan Tabel 6 diketahui bahwa nilai T hitung sebesar 3,166 dengan sig

0,003 yang berarti Ho ditolak atau pengalaman berpengaruh positif dan signifikan pada kualitas audit. Berdasarkan Tabel 6 diketahui bahwa nilai T hitung sebesar 18,944 dengan sig 0,00 yang berarti Ho ditolak atau Due professional care 
ISSN: 2302-8556

E-Jurnal Akuntansi Universitas Udayana

Vol.22.1. Januari (2018): 438-463

berpengaruh positif pada kualitas audit. Berdasarkan Tabel 6 diketahui bahwa nilai $\mathrm{t}$ hitung sebesar 10,277dengan sig 0,000 yang berarti Ho diterima atau Akuntabilitas auditor berpengaruh signifikan pada kualitas audit

Berdasarkan analisis statisik dalam penelitian ini ditemukan bahwa hipotesis pertama $\left(\mathrm{H}_{1}\right)$ pengalaman mempunyai pengaruh signifikan positif pada kualitas audit. Hasil penelitian ini menunjukkan bahwa pengalaman auditor searah dengan pelaksanaan kualitas audit tersebut. Hasil penelitian ini sejalan dengan Tubbs (1992) menyatakan bahwa auditor yang berpengalaman memiliki keunggulan antara lain mereka lebih banyak mengetahui kesalahan, mereka lebih akurat mengetahui kesalahan, mereka tahu kesalahan yang tidak khas dan pada umumnya hal-hal yang berkaitan dengan faktor-faktor kesalahan (ketika kesalahan terjadi dan tujuan pengendalian internal dilanggar) menjadi lebih menonjol. Teori keperilakuan menjelaskan hubungan antar variabel pengalaman auditor dengan kualitas audit. Auditor yang tidak berpengalaman akan melakukan atribusi kesalahan lebih besar dibandingkan dengan auditor yang berpengalaman (Wasito dan Ghozali, 2002:6). Jadi pengalaman mempengaruhi perilaku auditor yang kemudian akan mempengaruhi kualitas audit.

Pengalaman merupakan atribut yang penting dimiiki oleh auditor, hal ini terbukti dengan tingkat kesalahan yang dibuat oleh auditor yang tidak berpengalaman lebih banyak daripada auditor berpengalaman (Meidawati ,2001). Kebanyakan orang memahami bahwa semakin banyak jumlah jam terbang seorang auditor, tentunya dapat memberikan kualitas audit yang lebih baik daripada seorang auditor yang baru 
memulai karirnya. Atau dengan kata lain auditor yang berpengalaman diasumsikan dapat memberikan hasil kualitas audit yang lebih baik dibandingkan dengan auditor yang belum berpengalaman. Hal ini dikarenakan pengalaman akan membentuk keahlian seseorang baik secara teknis maupun secara praktis.

Secara teknis, semakin banyak tugas yang dia kerjakan, akan semakin mengasah keahliannya dalam mendeteksi suatu hal yang memerlukan perlakuan khusus yang banyak dijumpai dalam pekerjaannya yang sama secara terus menerus, maka akan menjadi lebih cepat dan lebih baik dalam menyelesaikannya. Hal ini dikarenakan dia telah benar-benar memahami teknik atau cara menyelesaikannya, serta telah banyak mengalami berbagai hambatan-hambatan atau kesalahan-kesalahan dalam pekerjaannya tersebut, sehingga dapat lebih cermat dan berhati-hati menyelesaikannya. Secara psikis, pengalaman akan membentuk pribadi seseorang, yaitu akan membuat seseorang lebih bijaksana baik dalam berpikir dan bertindak, karena pengalaman seseorang akan merasakan posisinya saat dia dalam keadaan baik dan saat keadaan buruk. Seseorang akan semakin berhati-hati dalam bertindak ketika ia merasakan fatalnya melakukan kesalahan. Dia akan merasa senang ketika berhasil menemukan pemecahan masalah dan akan melakukan hal serupa ketika terjadi permasalahan yang sama. Dia akan puas ketika memenangkan argumentasi dan akan merasa bangga ketika memperoleh imbalan hasil pekerjaannya (Bonner dan Lewis, 1990).

Hasil penelitian ini berbeda dengan penelitian yang dilakukan oleh Astrini (2014), Badjuri (2011), Kovinna dan Betri (2014), Melody Iskandar (2014) serta 
ISSN: 2302-8556

E-Jurnal Akuntansi Universitas Udayana

Vol.22.1. Januari (2018): 438-463

Singgih dan Bawono (2010) membuktikan bahwa pengalaman kerja tidak berpengaruh terhadap kualitas audit. Hasil tersebut sejalan dengan penelitian Aji (2009) dan Rahman (2009). Keduanya menyimpulkan bahwa tidak berpengaruhnya pengalaman pada kualitas audit disebabkan mungkin karena responden dalam penelitian mereka adalah auditor yang menjabat sebagai junior dan masa kerjanya belum lebih dari 3 (tiga) tahun sehingga respon para responden untuk menjawab pertanyaan berkaitan dengan variabel pengalaman cenderung menghasilkan jawaban tidak bernilai positif. Penggunaan faktor pengalaman sehubungan feedback yang berguna terhadap bagaimana sesuatu dilakukan secara lebih baik.

Berdasarkan analisis statisik dalam penelitian ini ditemukan bahwa hipotesis kedua $\left(\mathrm{H}_{2}\right)$ due professional care mempunyai pengaruh signifikan positif pada kualitas audit. Hasil penelitian ini menunjukkan bahwa due professional care auditor searah dengan pelaksanaan kualitas audit tersebut. Kualitas audit ditentukan oleh beberapa faktor, diantaranya adalah profesionalisme yang berpengaruh baik secara langsung maupun tidak langsung terhadap kualitas audit (Baotham, 2007:1). Akuntan publik memerlukan kecermatan yang memadai dalam pekerjaannya untuk menghasilkan kualitas audit yang baik dan menghindarkan dari terjadinya salah saji material dalam laporannya. Hasil penelitian ini juga didukung oleh teori yang dinyatakan oleh M. Guy (2002) yang menyatakan bahwa standar auditing merupakan standar otoritas yang harus dipenuhi auditor pada saat melaksanakan penugasan audit. Teori keperilakuan menjelaskan hubungan antara variable due professional care dengan kualitas audit. Teori keperilakuan yaitu suatu ilmu yang mempelajari perilaku 
manusia. Dalam ilmu keperilakuan terdapat tiga kontributor utama, yaitu psikologi, sosiologi, dan psikologi sosial. Psikologi dan psikologi sosial memberikan kontribusi banyak dalam perkembangan keperilakuan yaitu kepribadian, sikap, motivasi, persepsi, nilai, dan pembelajaran.

Due professional care adalah sikap mutlak yang lain yang harus dimiliki oleh seorang auditor. Ini berarti bahwa seorang auditor harus memiliki sikap yang cermat dan sungguh-sungguh dalam menjalankan profesinya sebagai auditor agar menghasilkan laporan audit yang berkualitas. Kecermatan dan keseksamaan menuntut auditor untuk selalu melaksanakan skepticme professional, yaitu suatu sikap yang mengharuskan auditor untuk berpikir kritis terhadap bukti audit yang ada dengan selalu mempertanyakan dan melakukan evaluasi terhadap bukti audit tersebut, berhati-hati dalam bertugas, serta tidak ceroboh dalam melakukan pemeriksaan dan memiliki keteguhan dalam melaksanakan tanggung jawab (Febriyanti R, 2014). Penelitian ini juga didukung oleh Mansur (2007:38) membuktikan bahwa masyarakat mempercayai laporan keuangan jika auditor telah menggunakan sikap skeptik profesionalnya dalam proses pelaksanaan auditnya. Auditor harus tetap menjaga sikap skeptik profesionalnya selama proses pemeriksaan, karena ketika auditor sudah tidak mampu lagi mempertahankan sikap skeptik profesionalnya, maka laporan keuangan yang diaudit tidak dapat dipercaya lagi, dan memungkinkan adanya litigasi paska audit.

Kantor Akuntan Publik (KAP) di Bali menerapkan kecermatan yang memadai dalam pekerjaannya dalam mencapai kualitas audit yang baik, diperlukan kecermatan 
ISSN: 2302-8556

E-Jurnal Akuntansi Universitas Udayana

Vol.22.1. Januari (2018): 438-463

dalam bidang tersebut sehingga menghasilkan kualitas audit yang baik juga. Hal ini dapat dibuktikan ketika seorang auditor telah memiliki sikap cermat dalam mengaudit laporan keuangan maka memungkinkan pemeriksa untuk mendapatkan keyakinan yang memadai bahwa salah saji material atau ketidakakuratan yang signifikan dalam data akan terdeteksi sehingga akan mendorong tercapainya kualitas audit. Ketika seorang auditor telah berpengalaman, independensi dan kecermataan dalam melaksanakan pekerjaannya maka setiap pekerjaan yang dikerjakan oleh orang yang ahli dengan standar yang jelas dan tidak ada keraguan lagi terhadap kualitas audit yang dihasilkan.

Berdasarkan analisis statisik dalam penelitian ini ditemukan bahwa hipotesis ketiga $\left(\mathrm{H}_{3}\right)$ akuntabilitas mempunyai pengaruh signifikan positif terhadap kualitas audit. Hasil penelitian ini sejalan dengan Libby dan Luft (1993) menyatakan bahwa seseorang dengan akuntabilitas tinggi maka akan memiliki motivasi yang tinggi dalam melaksanakan pekerjaannya. Cloud (1992) menambahkan bahwa seseorang yang mempunyai akuntabilitas tinggi akan mencurahkan pemikiran yang lebih besar dibandingkan dengan orang yang akuntabilitasnya rendah. Teori keperilakuan yaitu suatu ilmu yang mempelajari perilaku manusia. Teori keperilakuan menjelaskan hubungan antar variabel akuntabilitas dari seorang auditor terhadap kualitas audit, yang dimana akuntabilitas merupakan sikap pertanggungjawaban seorang auditor terhadap hasil audit yang dilakukan pada suatu perusahaan sehingga hasil audit tersebut lebih berkualitas dengan didasarkan oleh adanya bukti-bukti audit dan kertas kerja pemeriksaan audit. 
Hasil penelitian ini berbeda dengan penelitian yang dilakukan oleh penelitian yang dilakukan oleh Tan dan Kao (1999), Randi (2014), Febriyanti (2014) yang membuktikan bahwa akuntabilitas tidak berpengaruh terhadap kualitas audit. Hasil penelitian ini sejalan dengan Dea (2012) yang menyatakan akuntabilitas auditor tidak berpengaruh terhadap kualitas auditor dikarenakan kurang efektif dan efesiensinya pelayanan jasa audit terhadap kualitas hasil audit yang disampaikan. Sedangkan penelitian yang dilakukan oleh Lilis (2010) menguji akuntabilitas terhadap kualitas audit. Hasil penelitian ini menunjukan bahwa akuntabilitas berpengaruh signifikan terhadap kualitas audit. Sejalan dengan penelitian yang dilakukan Tetlock dan Kim (1987) juga meneliti pengaruh akuntabilitas terhadap proses kognitif seseorang. Hasil penelitiannya membuktikan bahwa subjek yang diberi instruksi diawal menjelaskan bahwa pekerjaan mereka akan diperiksa oleh atasan, melakukan proses kognitif yang lebih lengkap, memberikan respon yang lebih tepat dan melaporkan keputusan yang lebih realistis.

Jika seorang akuntan menyadari akan betapa besar perannya bagi masyarakat dan profesinya, maka ia akan memiliki sebuah keyakinan bahwa dengan melakukan pekerjaan dengan sebaik-baiknya, maka ia akan memberikan kontribusi yang sangat besar bagi masyarakat dan profesinya tersebut. Maka ia akan berkewajiban untuk memberikan yang terbaik bagi masyarakat dan profesinya tersebut dengan melakukan pekerjaannya sebaik mungkin. Pada Kantor Akuntan Publik di Bali telah menyadari bahwa profesi sebagai akuntan publik memiliki tanggungjawab yang besar dengan melakukan pekerjaannya dengan sebaik mungkin demi masyarakat dan profesinya 
ISSN: 2302-8556

E-Jurnal Akuntansi Universitas Udayana

Vol.22.1. Januari (2018): 438-463

tersebut. Sehingga telah melaksanakan bentuk dari tanggung jawab seorang auditor diantaranya adalah tanggung jawab atas melaporkan kecurangan, kekeliruan, ketidakberesan, mempertahankan sikap independensi, menemukan tindakan melanggar hukum dari klien dan mengkomunikasikan informasi yang berguna tentang hasil audit (SPAP, 2011). Hal ini menunjukkan bahwa meningkatnya akuntabilitas suatu Kantor Akuntan Publik (KAP) akan berpengaruh terhadap peningkatan pada kualitas audit yang dihasilkan. Artinya semakin tinggi akuntabilitas atau tanggungjawab profesional auditor maka akan meningkatkan kualitas audit yang dihasilkan.

\section{SIMPULAN}

Berdasarkan analisis data dan pembahasan yang telah dilakukan, maka dapat disimpulkan bahwa (1)pengalaman auditor berpengaruh positif pada kualitas audit; (2) due professional careauditor berpengaruh positif pada kualitas audit; dan (3) akuntabilitas auditor berpengaruh positif pada kualitas audit. Sebagai implikasinya, Kantor Akuntan Publik diharapkan untuk dapat terus meningkatkan lagi pengalaman kerja, due professional care dan akuntabilitas setiap auditornya. Faktor-faktor tersebut terbukti mampu meningkatkan dan mempengaruhi kualitas audit yang akan berdampak positif bagi kinerja auditor secara individual dan kinerja Kantor Akuntan Publiksecara keseluruhan. Penelitian ini merekomendasikanpenelitian selanjutnya yang mengkaji dan mereplikasi penelitian ini dapat menambah variabel-variabel lain 
yang juga merupakan indikator-indikator penting yang dapat mempengaruhi kualitas audit.

\section{REFERENSI}

Aji, Pandhit Seno. 2009. Faktor-faktor yang Mempengaruhi Kualitas Audit Ditinjau dari Persepsi Auditor atas Independensi, Pengalaman, dan Akuntabilitas. Skripsi. Fakultas Ekonomi Universitas Jenderal Soedirman. Purwokerto. (Tidak dipublikasikan).

Anderson, John C, Marianne M. Jennings, D. Jordan Lowe dan Philip M. J. The Mitigation of Hindsight Bias in Judges' Evaluation of Auditor Decisions. Auditing: A Journal of Practice and Theory. 16(20). 20-39.

Ardini, Lilis. 2010.Pengaruh Kompetensi, Independensi, Akuntabilitas dan Motivasi Terhadap Kualitas Audit.Majalah Ekonomi, (3). STIESIA. Surabaya.

Asih, Dwi Ananing Tyas. Jurnal. Pengaruh Pengalaman Terhadap Peningkatan Keahlian Auditor Dalam Bidang Auditing. Skripsi. Fakultas Ekonomi Universitas Islam Indonesia. Yogyakarta.

Badjuri, Achmad. 2011. Faktor-faktor yang Berpengaruh terhadap Kualitas Audit Auditor Independen Pada Kantor Akuntan Publik (KAP) di Jawa Tengah. Dinamika Keuaangan dan Perbankan 3(2), 183 - 197.

Baotham, Sumintorn, Effects of Professionalism on Audit Quality and Self-image of CPAs in Thailand, International Journal of Bussiness Strategy, 2007.

Bawono, I. R., dan E. M . Singgih. 2010. Pengaruh independensi, pengalaman, due professional care dan akuntabilitas terhadap kualitas audit (studi pada KAP 'big four' di Indonesia). Simposium Nasional Akuntansi XIII.

Bernardin, A Richard. 1994. Fraud Detection: The Effect of Client Integrity and Competenceand Auditor Cognitive Style. Auditing: A Journal of Practise \& Theory, 13.

Bonner, S.E., Lewis, B.L. (1990). Determinants of Auditor Expertise. Journal of Accounting Research, 28, 1-20

Cloud, C. Bryan., (1997), Performance in Research Task: The Joint Effect of Knowledge and Accountability, Journal Of Accounting Research, 249-273 
ISSN: 2302-8556

E-Jurnal Akuntansi Universitas Udayana

Vol.22.1. Januari (2018): 438-463

Cushing, B.E. 1999. Economic Analysis of Accountants. Ethical Standards: The Case of Audit Opinion Shopping. Journal of Accounting and Public Policy. pg. 339363

DeAngelo, Linda Elizabeth., 1981. Auditor Independence, 'Low Balling', and Disclosure Regulation, Journal of Accounting and Economic, 3(3), January 1981, 113-127.

Diani dan Ria. 2007. Pengaruh Akuntabilitas dan Pengetahuan terhadap Kualitas Hasil Kerja Auditor. Symposium Nasional Akuntansi X. IAI. Makassar.

Donald L. Deis Dan Gari A. Giroux. 1992. Determinants of Audit Quality In The Public Sector. The Accounting Review, 67(3), 462-479

Edosa, Joshua Aronnmwan, Tina Oghenekome Ashafoke, and Chijoke Oscar Mgbame. 2013. Audit Firm Reputation and Audit Quality.European Journal of Bussiness and Management, 5(7).

Elfarini. Eunike Christina. 2007. Pengaruh Kompetensi dan Independensi Auditor terhadap Kualitas Audit. Penelitian. Universitas Negeri Semarang.

Febriyanti, Reni. 2014. Pengaruh Independensi, Due Professional Care dan Akuntabilitas Terhadap Kualitas Audit (Studi Empiris Pada Kantor Akuntan Publik di Kota Padang dan Pekanbaru. Skripsi. Universitas Negeri Padang Fakultas Ekonomi Program Studi Akuntansi.

Guy, M. Dan Wayne Alderman, dan Alan J. Winters, 2002. Auditing, Edisi kelima, alih Bahasa Sugiyarto, SE, M.Si, Ak. Auditing, Jilid 1, Erlangga, Jakarta

Harhinto, Teguh. 2004. Pengaruh Keahlian dan Independensi terhadap Kualitas Audit Studi Empiris Pada KAP di Jawa Timur. Semarang. Tesis: Universitas Diponegoro.

Indriantoro, Dr. Nur, M.Sc., Ak dan Drs. Bambang Supomo, M. Si., Ak. 2002. Metodologi Penelitian Bisnis untuk Akuntansi dan Manajemen. Edisi ke-1. BPFE. Yogyakarta.

International Standard Auditing (ISA). 2012. Handbook of International Quality Control, Auditing, Review, Other Assurance and Related Service Pronouncments. International Federation of Accountants. 
Iskandar, M. 2014. Pengaruh independensi, pengalaman, pengetahuan, due professional care, akuntabilitas, dan kepuasan kerja terhadap kualitas audit (Studi empiris pada KAP di Semarang). Universitas Katolik Soegijapranata

Kamus Besar Bahasa Indonesia. 1997. Edisi Kedua. Departemen Pendidikan dan Kebudayaan. Balai Pustaka

Kovinna, Fransiska dan Betri. 2014. Pengaruh Independensi, Pengalaman Kerja, Kompetensi, Dan Etika Auditor Terhadap Kualitas Audit (Studi Kasus pada Kantor Akuntan Publik di Palembang. Palembang. Sekolah Tinggi Ilmu Ekonomi Multi Data Palembang.

Libby, R dan Luft, J. 1993. Determinants of judgement performance in accounting settings: ability, knowledge, motivation and environment. Accounting Organization and Society.

Louwers, Timothy J., Elaine Henry, Brad J, Reed, \& Elizabeth, A, Gordon. (2008). Deficiencies in Auditing Related-Party Transaction: Insights from AAERs. Current Issues in Auditing. 2(2), 10-16.

Kadous, Kathryn.2000. The Effects of Audit Quality and Consequence Severity on Juror Evaluations of Auditor Responsibility for Plaintiff Losses. The Accounting Review. 75(3), pp. 327-341.

Mansur, Tubagus. 2007. Faktor-Faktor yang Mempengaruh Kualitas Audit Ditinjau dari Persepsi Auditor atas Pelatihan dan Keahlian, Independensi dan Penggunaan Kemahiran Profesional. Tesis Program Studi Magister Sains Akuntansi Universitas Gajah Mada (Tidak dipublikasikan).

Meidawati, Neni. 2001. Jurnal. Meningkatkan Akuntabilitas Auditor Independen Melalui Standar Profesional. Media Akuntansi

Messier William dan Quilliam William. 1992. The Effect of Accountability on Judgement Development Hypothesis for Auditing. Journal of Practice and Theory. 123-138.

Rahman, Ahmad Taufik. 2009. Persepsi Auditor Mengenai Pengaruh Kompetensi, Independensi, dan Due Professional Care terhadap Kualitas Audit. Skripsi. Fakultas Ekonomi Universitas Jenderal Soedirman. Purwokerto, (Tidak dipublikasikan). 
ISSN: 2302-8556

E-Jurnal Akuntansi Universitas Udayana Vol.22.1. Januari (2018): 438-463

Randi, Sri Vadilla. 2014. Pengaruh Kompetensi, Independensi, Akuntabilitas dan Pengalaman, Due Professional Care dan Motivasi terhadap Kualitas Audit. Skripsi. Surakarta: Fakultas Ekonomi dan Bisnis. Universitas Muhammadiyah Surakarta.

Robbins, Stephen P. and Timothy. A. Judge. 2008. Perilaku Organisasi Edisi 12. Jakarta. Penerbit Salemba Empat

Rosnidah, Ida. Rawi dan Kamarudin. 2010. Analisis Dampak Motivasi Dan Profesionalisme Terhadap Kualitas Audit Aparat Inspektorat Dalam Pengawasan Keuangan Daerah (Studi Empiris Pada PemerintahKabupaten Cirebon). Jurnal Akuntansi. Bandung..

Saripudin, Netty Herawaty, dan Rahayu, 2012. Pengaruh Independensi, Pengalaman, Due Professional Care, dan Akuntabilitas Terhadap Kualitas Audit (Survei Terhadap Auditor KAP di Jambi dan Palembang. E-Jurnal Binar Akuntansi. $1(1)$.

Singgih, dkk. 2010. Pengaruh Independensi, Pengalaman, Due Professional Care dan Akuntabilitas Terhadap Kualitas Audit. SNA XIII Purwokerto.

Standar Profesional Akuntan Publik (SPAP). 2011. PSA No. 04 SA Seksi 230. Institut Akuntan Publik Indonesia. Jakarta

Sugiyono. 2013. Metode Penelitian Kuantitatif Kualitatif dan R\&D. Bandung : CV. Alfabeta

Sugiyono.2010.Metode Penelitian Bisnis.Bandung:CV. Alfabeta.

Tan, Tong Han dan Alison Kao, (1999), Accountability Effects on Auditor's Performance: The Influence of Knowledge, Problem Solving Ability and Task Complexity, Journal of Accounting Research, 209-223.

Tetlock, PE dan J.L Kim. 1987. Accountability and judgment processes in a personality prediction risk. Journal of Personality and Social Pshycology. 1987

Tubbs, R.M. 1992. The Effect of Experience on the Auditor's Organization and Amount of Knowledge. The Accounting Review, 67(4), 783-801.

Wasito \& Ghozali, I.2002. Pengaruh Sistem Pengendalian Terhadap Prestasi Kerja: Uji Langsung dan Tidak Langsung. Jurnal Ekonomi dan Bisnis (Dian Ekonomi). 8(2). 
Ni Made Widia Iswara Dewi dan I Putu Sudana. Pengaruh ...

Wiratama, William Jefferson dan Ketut Budiartha. 2015. "Pengaruh Independensi,

Pengalaman Kerja, Due Professional Care DanAkuntabilitas Terhadap Kualitas Audit”. Jurnal Akuntansi. ISSN 23028578. 